\title{
The determinants of murabaha margin income in Islamic banking companies in Indonesia
}

\author{
M Musaroh', Naning Margasari², Nindya Nuriswati Laili³ ${ }^{3}$ and Mahendra Ryansa Gallen Gagah ${ }^{4}$ \\ 1,2,3,4 Management Department, Faculty of Economics, Yogyakarta State University, Indonesia
}

\begin{abstract}
This research was conducted to examine the effect of the operational costs, third-party funds, murabaha financing volume, Bank Indonesia's interest rate and inflation on murabaha margin income at Islamic commercial banks in Indonesia. The period used in this research is 3 years, from 2016 to 2018. This study's population were 14 Islamic commercial banks that have been and are still registered with the Financial Services Authority from 2016 to 2018 . The sampling technique used was purposive sampling and obtained a sample of 9 Islamic commercial banks. The data analysis technique used is multiple linear regression. Before conducting the multiple linear regression analysis, a classic assumption test was carried out to ensure that the model did not have normality, heteroscedasticity, autocorrelation, and multicollinearity. The results show that partially operational costs have a positive and significant effect on murabaha margin income, third-party funds have a negative and significant effect on murabaha margin income, murabaha financing volume has a positive and significant effect on murabaha margin income, while the Bank Indonesia's interest rate and inflation do not influence on Murabaha margin income.
\end{abstract}

Keywords operational costs; third-party funds; murabaha financing volume; Bank Indonesia's interest rate; inflation; murabaha margin income

\section{INTRODUCTION}

Murabaha financing is a contract to finance an item by notifying the buyer's purchase price and the buyer paying it at a higher price as an agreed profit (Antonio, 2001). The amount of profit margin or profit level on murabaha financing set by the Islamic bank and agreed by the bank and its customers (UU no 21, 2008). Based on the Indonesian Sharia Banking Statistics, for October 2018, the total financing based on the murabaha receivable contract was 154.756 billion Rupiah. The amount of financing provided in the murabaha agreement undoubtedly affects the amount of profit earned by Islamic banking.

This type of murabaha financing dominates the lending of Islamic banking in Indonesia (Africa, 2020). This condition is understandable, considering that this type of financing is considered to have a lower risk than other financing types (Harahap et al.,
2005). Also, the rate of return determined from the beginning makes it easier for banks to predict the profit that will be obtained while judging by customer perspective, murabaha financing is relatively easy to understand by the public, given the similarities in the operation of the murabaha contract with the types of credit that micro-businesses have practiced.

Operational costs are all costs incurred by bank in its operational activities consisting of labor costs, administrative and general costs, depreciation costs, reserve costs for earning assets write-offs, and other costs related to bank operations or in other words, operational costs are all costs incurred by banks in carrying out their operations both in raising funds and distributing funds (Sulhan, 2008). Banks need to pay attention to the operational costs they incur in determining revenue not to suffer losses and obtain optimal profits to continue to operate. 
Third-party funds (DPK) are funds collected by banks from their customers consisting of savings, current accounts, and time deposits. the bank has collected third-party funds will be channeled back in the form of financing as the bank functions as an intermediary institution (Riyadi, 2006). In addition to being required to comply with sharia regulations, Islamic banking is also expected to be able to provide profit sharing to third parties at least equal to or even greater than the prevailing interest rate in conventional financial institutions and to apply a financing profit margin that is lower than the loan interest rate applies to conventional financial institutions (Rahmawati \& Rokhman, 2015). Third-party funds in Islamic banking continued to increase, wherein 2018 there was an increase of $18.01 \%$ (databoks.katadata.co.id, accessed on $21^{\text {st }}$ August 2020). This increase has made financing in Islamic banking increased so that banks can profit and provide greater profitsharing than before due to an increase in the amount of financing.

The volume of financing is the portion determined by the bank in its overall financing. Murabaha is the most dominant financing product in Islamic banking, where the portion of murabaha in Islamic banking financing based on Sharia Banking Statistics in December 2018 is $56.26 \%$. The high volume of financing makes the bank have a high financing risk, and the bank must provide a low margin or ratio to customers to reduce the risk of this financing. Low margins will make these products attractive to customers, so bank can get many customers, which means income and profits from murabaha financing will be even greater.

Fixed income means that Islamic banking can face the risk of experiencing potential loss. The risk of experiencing a potential loss can occur if there are factors that have changed, such as the Bank Indonesia's reference interest rate during the payment period has increased where the bank cannot get more profit because profit margin has been agreed upon in advance and fixed (lqbal \& Mirakhor, 2007). Besides the reference interest rate, banks also need to pay attention to inflation because it will fluctuate in value during the payment period. Meanwhile, the bank cannot increase their income to solve this problem because the marginal income from Murabaha financing has been previously agreed upon by bank and customer and permanent so bank cannot change it.
Our exploration of the previous literature shows that there are several fundamental problems related to murabaha: (1) the income set by Islamic banking tends to be the same or even more significant than the credit interest set by conventional banks and there is also no provision that regulates the determination of murabaha income; (2) murabaha financing is still the most dominant financing portion of Islamic banking; (3) murabaha income, which is fixed in nature, makes Islamic banking potentially experience loss; (4) sharia banking still uses the seven days repo rate as a reference for determining murabaha income so that conventional explanations still influence the murabaha income of Islamic banking.

Therefore, by using data from Islamic banking registered with the Financial Services Authority (OJK) from 2016-2018, this paper examines the effect of operational costs, thirdparty funds, and murabaha financing volume on the murabaha margin income. Furthermore, this study also uses descriptive factors that conventional banks also use as a descriptive factor of murabaha income. These factors are the seven days repo rate and inflation, where previous studies only a few included these factors, especially inflation in explaining Murabaha income.

\section{LITERATURE REVIEW AND HYPOTHESES DEVELOPMENT}

\section{Murabaha margin determination}

Murabaha margin is the percentage level of profit determined by the bank in murabaha contract. In determining the murabaha margin, Islamic banking needs to pay attention to several things (Karim, 2010), namely: (1) direct competitor's market rate (DCMR) represents the average profit margin level of Islamic banking or the average profit margin level of several Islamic banks as determined in the asset-liability committee (ALCO) meeting as direct competitors; (2) indirect competitor's market rate (ICMR) which is the average interest rate of conventional banks or the average interest rate of several conventional banks which in the asset-liability committee (ALCO) was determined as a group of indirect competitors; (3) expected competitive return for investors (ECRI); and (4) expected competitive return for investors (ECRI) which is a competitive profit-sharing 
target that is expected to provide funds to third parties. This should be noted because the bank must provide compensation and incentives for funds managed from third parties following the agreement in the beginning of the transaction; (5) acquiring cost, which represents costs incurred by a bank that is directly related to efforts to obtain third-party funds.(6) the overhead cost, which is a cost incurred by the bank, is not directly related to efforts to obtain third-party funds.

\section{Operational costs}

Operational costs are costs related to the company's operations consisting of sales costs, administrative and general costs, where all these costs are charged to revenue in the period the costs occur. Another definition of operational costs is the costs incurred by a bank in its operational activities consisting of labor costs, general and administrative costs, depreciation costs, reserve costs for earning asset write-offs, and other costs related to Islamic banks' operation. The efficiency of banking activities can be seen from several perspectives, as was done in the research of Trinugroho et al. (2014). Research from Demirgüc-Kunt and Huizinga (1999), Maudos and Guevara (2004) and Hawtrey and Liang (2008) examined the impact of overhead costs on banking performance. Based on this explanation, it can be interpreted that operational costs are costs incurred by a bank in carrying out its operations.

H1: Operational costs have a positive effect on murabaha margin income.

\section{Third-party funds}

Third-party funds represent the bank's total funds from customers, consisting of savings, current accounts, and deposits. Third-party funds collected by Islamic banks will be channeled back to their customers according to the function of the bank as an intermediary institution so that the increasing third-party funds will increase the financing of Islamic banks. As an intermediary institution, the bank must comply with laws and regulations and careful in carrying out its function as a channel for funds in financing murabaha. Short-term deposits consist of savings, current accounts and time deposits allocated to financing activities that have a short term as well to reduce bank risk. (Linda, 2019). The increasing of financing will make murabaha financing to be increased because of murabaha financing most dominant in Islamic banking so that with the increase in third-party funds, the bank will reduce the revenue the margin to increase the number of customers that will increase profits and can provide for great results against third-party funds. Based on this description, it can be concluded that third-party funds negatively influence murabaha margin income.

H2: Third-party funds have a negative effect on murabaha margin income.

\section{Murabaha financing volume}

Murabaha financing volume is the portion of the murabaha contract the entire financing contract issued by the bank. The greater the financing of a contract, the contract is the leading contract or the most dominating of the bank's financing. Saeed (1998), finds that the murabaha financing model becomes dominant since it is a short-term investment mechanism. Another reason is that the markup in the murabaha system can be determined so that it can be assured that Islamic financial institutions will gain their profit in such away. Najjar (2011) says that murabaha becomes dominant since it has low risk. Usmani (2003) proposes several reasons for murabaha financing domination in the investment operation of Islamic banking. The first is that murabaha is a short-term investment mechanism and the second is that the murabaha prevents the capital owner from interfering with business management.

This high volume of financing makes banks have to provide margins or low ratios to customers to make the product attractive to customers so that the bank can obtain many customers, which means income and the profits obtained by the bank from murabaha financing will be even higher. Conversely, if the financing volume decreases, the bank will increase its margin income. This is done so that the bank continues to make a profit even though customers fail to make installments. Based on the description, it can be concluded that the volume of murabaha financing has a 
Table 1.

List of Islamic Commercial Banks used as Research Samples)

\begin{tabular}{ll}
\hline No. & Company name \\
\hline 1 & PT. Bank Muamalat Indonesia \\
2 & PT. Bank BRI Syariah \\
3 & PT. Bank Jabar Banten Syariah \\
4 & PT. Bank BNI Syariah \\
5 & PT. Bank Mega Syariah \\
6 & PT. Panin Dubai Syariah Bank \\
7 & PT. Bukopin Islamic Bank \\
8 & PT. BCA Syariah \\
9 & PT. Sharia National Pension Savings Bank \\
\hline
\end{tabular}

negative influence on the level of murabaha income.

\section{H3: Financing volume has a positive effect on murabaha margin income.}

\section{Interest rate (seven days repo rate)}

Bank Indonesia's interest rate is the bank's interest rate issued by Indonesian banks and become a reference for other banks to determine their interest rate. The absence of provisions governing the determination of murabaha financing margins makes Islamic banking in Indonesia still making the seven days repo rate as one of the references in revenue determination the margins of the mullah. This means that if the seven days repo rate increases, the bank will increase its income in anticipation of an increase in interest rate so that the bank does not experience real losses because the bank cannot change the agreed price. Alfarda (2018) states that Islamic bank in Indonesia (sharia commercial banks and sharia business units) influence by seven days repo rate. Based on this description, it can be concluded that Bank Indonesia's interest rate positively influence murabaha margin income.

H4: Interest rate has a positive effect on murabaha margin income.

\section{Inflation}

Inflation is a condition where there is an increase in various commodities' prices due to several factors such as too much money in circulation. It is the factor that must also be considered in terms of determining profit margins so that banks can still enjoy profits even though there is high inflation at some point during the payment period. In the event of a decrease in the inflation rate, banks should reduce their margin income because margin income equal to or greater than conventional bank interest rate can damage the reputation of Islamic banks and high margin income, which can also indirectly cause an increase in inflation rate (Muhammad, 2002).

Banks do not anticipate inflation in the short term, the interest rate does not reflect an increase in inflation, but in the medium and long term, banks will adjust their interest rate to compensate for the inflation premium and ultimately increase the net interest margin (Tarus et al., 2012). Demirgüc-Kunt et al. (1999) found a positive relationship between inflation and net interest margin in their research with a global sample of 80 countries. In contrast, Abreu and Mendes in Islam and Nishiyama (2016) found a negative relationship between inflation rate and banking performance in studies in Portugal, Spain, France and Germany. Based on the description, it can be concluded that inflation has a positive influence on murabaha margin income.

H5: Inflation has a positive effect on
murabaha margin income.

\section{METHODS}

This study uses financial statement data for Islamic commercial banks registered with the Financial Services Authority for 2016-2018. There are 14 Islamic commercial banks which are the population of this study. The research sample was taken by purposive sampling, that is, sampling with specific criteria. The sampling criteria in this study are (1) Islamic commercial banks that have been and are still registered with the Financial Services Authority from 2016 to 2018; (2) Islamic 
Table 2.

Descriptive statistics

\begin{tabular}{|c|c|c|c|c|}
\hline Variable & Minimum & Maximum & Mean & $\begin{array}{l}\text { Std. } \\
\text { Deviation }\end{array}$ \\
\hline $\begin{array}{l}\text { Murabaha income (in } \\
\text { million rupiah) }\end{array}$ & 103,257 & 896,307 & 309,486 & 183,318 \\
\hline $\begin{array}{l}\text { Operational costs (in } \\
\text { million rupiah) }\end{array}$ & 158,421 & $2,942,787$ & 761,207 & 498,841 \\
\hline $\begin{array}{l}\text { Third-party funds (in } \\
\text { million rupiah) }\end{array}$ & $3,179,564$ & $48,635,487$ & $11,404,733$ & $11,679,884$ \\
\hline $\begin{array}{l}\text { Murabaha financing } \\
\text { volume (in million } \\
\text { rupiah) }\end{array}$ & 978,018 & $20,224,479$ & $5,954,897$ & $5,198,349$ \\
\hline $\begin{array}{l}\text { Bank Indonesia's } \\
\text { interest rate (\%) }\end{array}$ & 4.25 & 6.00 & 4.86 & 0.53 \\
\hline Inflation (\%) & 2.79 & 4.37 & 3.45 & 0.37 \\
\hline
\end{tabular}

commercial banks that publish their financial reports continuously during the study period, namely 2016-2018; (3) Islamic commercial banks did not experience losses during the study period, namely 2016-2018; and (4) Islamic commercial banks that have complete data needed in the study. Based on these criteria, 9 Islamic commercial banks were used as research samples. Table 1 shows the list of Islamic commercial banks used as research samples.

The data analysis technique used in this study is multiple linear regression analysis. This model is used to explain the relationship and influence of the independent variable on the dependent variable. Multiple linear regression analysis in this study is used to determine the effect of operational costs, thirdparty funds, volume of murabaha financing, Bank Indonesia's interest rate, and inflation on murabaha margin income of Islamic commercial banks registered with the Financial Services Authority for the 2016-2018 period.

Before multiple linear regression analysis is carried out, a classic assumption test is carried out first to ensure that the model does not have normality, heteroscedasticity, autocorrelation, and multicollinearity. If the model used passes the test, the model is suitable for use.

The multiple linear regression equation is as follows:

$$
\begin{gathered}
P M M=\alpha+\beta_{1} \cdot B O P+\beta_{2} \cdot D P K+\beta_{3} \cdot V P M \\
+\beta_{4} \cdot B I+\beta_{5} \cdot I+e
\end{gathered}
$$

Descriptive statistical analysis in this study includes the minimum value, maximum value, mean and standard deviation. The results of the detailed data description for each variable can be seen in Table 2.

\section{RESULTS AND DISCUSSION}

\section{Effect of operational costs on murabaha margin income}

The results of multiple regression analysis shown in Table 3 indicate that the operational cost variable had a regression coefficient value of 0.563 with a significance value of 0.000 . The operational cost variable's significance level is smaller than the expected significance level $(0.05)$, of $0.000<0.05$. This indicates that variable operational costs have a positive effect on murabaha margin income.

Operational costs represent all costs incurred by the bank in carrying out its operations. Efficient management makes the bank's operational costs lower. Low operational costs have led banks to lower their margin revenue to increase the number of customers who buy murabaha products so that revenue from murabaha financing increases. On the other hand, the increased operational costs to keep the bank's income more significant than its operational costs so that it does not suffer losses.

These results are consistent with research by Asmita (2004), Heykal (2004) and Nugraha (2005). In this study, there is a significant influence between operational costs on the margin of Murabaha financing. This shows that the object under study considers the number of operational costs in determining Murabaha margin financing. 


\section{Effect of third-party funds on murabaha margin income}

The results of multiple regression analysis shown in Table 3 also indicate that the variable party funds have a regression coefficient value of -0.316 with a significance value of 0.000 . The third-party fund variable's significance level is smaller than the expected significance level $(0.05)$, of $0.000<0.05$. This indicates that the third-party funds have a negative effect on murabaha margin income.

Third-party funds are funds obtained by banks from customers consisting of savings, current accounts and time deposits. Thirdparty funds will be channeled back by the bank to its customers. The more third-party funds increase, the greater the Islamic bank financing. Increasingly increasing financing will make murabaha financing increase. Thus, with the increase in third-party funds, the bank will reduce its margin income to increase the number of customers to increase its profit and provide large profit-sharing with third-party funds.

These results follow Haryanti (2016), which found a negative and significant influence between third-party funds on Murabaha margin financing. This indicates that with the increase in third-party funds, the bank will provide a large profit-sharing, so the Murabaha margin income will decrease.

\section{The effect of murabaha financing volume on murabaha margin income}

The results of multiple regression analysis shown in Table 3 also indicate that murabaha financing volume has a regression coefficient value of 0.592 with a significance value of 0.000 . The level of significance of the murabaha financing volume value is smaller than the expected significance level (0.05), of $0.000<0.05$. This indicated murabaha financing volume variable has a positive effect on murabaha margin income.

Murabaha financing volume is the amount of the murabaha contract portion in the bank's entire financing contract. Murabaha financing is the financing that dominates the financing of Islamic banks. The greater the volume of murabaha financing provided by Islamic banks, the greater the bank's margin.

These results are following Sri (2018) and Fara (2018), this study found a significant influence between Murabaha financing on
Murabaha margin financing. This shows that an increase in murabaha financing volume will increase the amount of murabaha margin income received by Islamic banks.

\section{The effect of Bank Indonesia's interest rate on murabaha margin income}

The results of multiple regression analysis shown in Table 3 also indicate that Bank Indonesia's interest rate has a regression coefficient value of 0.067 with a significance value of 0.188 . The interest rate of Bank Indonesia is greater than the expected level of significance $(0.05)$ of $0.188>0.05$. This indicates that Bank Indonesia's interest rate does not positively affect murabaha margin income.

The Bank Indonesia's interest rate has no significant effect on Murabaha margin income. This is because the Bank Indonesia's interest rate data used in the study has little variation or slight difference.

\section{Effect of inflation on murabaha margin income}

The results of multiple regression analysis shown in Table 3 also suggest that inflation has a regression coefficient value of 0.043 with a significance value of 0.549 . The level of significance of the variable's inflation value is greater than the expected significance level (0.05), of $0.549>0.05$. This indicates that variable inflation has no positive effect on murabaha margin income.

Inflation has no significant effect on murabaha margin income. This is because the inflation data used in the study has little variation or only a slight difference.

\section{CONCLUSION}

This study aims to determine the effect of operational costs, third-party funds, volume of murabaha financing, Bank Indonesia's interest rate, and inflation on murabaha margin income at Islamic commercial banks registered with the Financial Services Authority for the 20162018 period. Based on multiple linear regression analysis, it can be concluded that the research results of operational costs have a positive effect on murabaha margin income. The analysis results show that the resulting significance value is smaller than the required 
significance value of $0.000<0.05$ with a positive regression coefficient of 0.563 . Based on these results, it can be concluded that operational costs have a positive effect of $56 \%$ on murabaha margin income. Third-party funds have a negative effect on murabaha margin income. The analysis results show that the resulting significance value is smaller than the required significance value, namely 0.000 $<0.05$ with a negative regression coefficient of -0.316 . Based on these results it can be concluded that third-party funds have a negative effect of $31.6 \%$ on murabaha margin income. murabaha financing volume has a positive effect on murabaha margin income. The analysis results show that the resulting significance value is smaller than the required significance value, namely $0.000<0.05$ with a positive regression coefficient of 0.592 . Based on these results, it can be concluded that the volume of murabaha financing has a positive effect of $59.2 \%$ on murabaha margin income. The Bank Indonesia's interest rate does not affect murabaha margin income. The analysis results show that the resulting significance value is greater than the required significance value, namely $0.188>0.05$. Based on these results, the Bank Indonesia's interest rate does not affect murabaha margin income. Inflation does not affect murabaha margin income. The analysis results show that the resulting significance value is greater than the required significance value, namely $0.549>$ 0.05 . Based on these results, the Bank Indonesia's interest rate does not affect murabaha margin income. 188>0.05. Based on these results, the Bank Indonesia's interest rate does not affect murabaha margin income. Inflation does not affect murabaha margin income. The analysis result shows that the resulting significance value is greater than the required significance value, namely $0.549>$ 0.05 . Based on these results, the Bank Indonesia's interest rate does not affect murabaha margin income. 188>0.05. Based on these results, the Bank Indonesia's interest rate does not affect murabaha margin income. Inflation does not affect murabaha margin income. The analysis results show that the resulting significance value is greater than the required significance value, namely $0.549>$ 0.05 . Based on these results, the Bank Indonesia's interest rate does not affect murabaha margin income.

This study has several limitations. This research only uses Islamic commercial banks as the research sample so that it is less representative of all Islamic banking, which consists of Islamic commercial banks, Islamic business units, and Islamic public financing. This study only uses explanatory variables in operational costs, third-party funds, murabaha financing volume, Bank Indonesia's interest rate, and inflation. In future studies, it is hoped that a different research method can be used or a robustness check is used for better results.

Based on the conclusions and limitations described earlier, the suggestions that can be given are, for further researchers it is expected to be able to add research samples, not only Islamic commercial banks but also including Islamic business units and Islamic people's financing and it is hoped that they will add other variables that can affect income. Murabaha margin. The bank is expected to pay more attention to the three influencing variables such as operational cost variables, third-party funds and murabaha financing volume. Regulators or the government are expected to form clearer regulations regarding Islamic banking, both in terms of accounting and macro regulations.

\section{REFERENCES}

Africa, L. A. (2020). Determinasi Pembiayaan Murabahah Berbasis Analisis Resiko Pada Bank Umum Syariah di Indonesia. Jurnal Riset Akuntansi \& Perpajakan (JRAP), 7(01), 43-52.

Alfarda, W. N., (2018). Pengaruh BI 7-Day (Reverse) Repo Rate Dan Penempatan Dana Pada Bank Indonesia Terhadap Tingkat Likuiditas Pada Bank Umum Syariah Dan Unit Usaha Syariah. Undergraduate thesis on IAIN Tulung Agung.

Ali, Z. (2008). Hukum Perbankan Syariah. Jakarta: Sinar Grafik Allen, L. (1988). The determinants of bank interest margins: A note. Journal of Financial and Quantitative analysis, 231-235.

Al-Najjar, B., \& Belghitar, Y. (2011). Corporate cash holdings and dividend payments: Evidence from simultaneous analysis. Managerial and decision Economics, 32(4), 231-241.

Angbazo, L. (1997). Commercial bank net interest margins, default risk, interest-rate risk, and off-balance sheet banking. Journal of Banking \& Finance, 21(1), 55-87. 
Antonio, M. S. (2001). Bank Syariah: Dari Teori ke Praktik. Jakarta: Gema Insani Press.

Aydemir, R., \& Guloglu, B. (2017). How do banks determine their spreads under credit and liquidity risks during business cycles?. Journal of International Financial Markets, Institutions and Money, 46, 147157.

Aydemir, R., Guloglu, B., 2015. "How do banks determine their spreads under credit and liquidity risks during business cycles?" Journal of International Financial Markets, Institutions \& Money.

Chen, S. H., \& Liao, C. C. (2011). Are foreign banks more profitable than domestic banks? Home-and host-country effects of banking market structure, governance, and supervision. Journal of Banking \& Finance, 35(4), 819-839.

Demirguc-Kunt, A., \& Huizinga, $H$. (1998). Determinants of commercial bank interest margins and profitability: some international evidence (No. 1900). The World Bank.

Fara, (2018). Analisis Dana Pihak Ketiga, NonPerforming Financing, dan Financing to Deposit Ratio dalam Pembiayaan Murabahah pada Bank Mandiri syariah, Jurnal Fakultas Ekonomi, Universitas Gunadarma, 1-13

Greuning, H. V. \& lqbal, Zamir. (2011). Analisis Risiko Perbankan Syariah. Jakarta: Salemba Empat.

Gujarati, D. (2003). Ekonometri Dasar. Terjemahan: Sumarno Zain. Jakarta: Erlangga.

https://databoks.katadata.co.id/datapublish/2019/0 4/15/berapa-dana-pihak-ketigaperbankan-syariahindonesia\#: :text=Dana\%20Pihak\%20Ke tiga\%20(DPK)\%20perbankan,)\%20Rp\%2 $016 \% 2$ C51\%20triliun, accessed on $21^{\text {st }}$ August 2021.

Indriantoro. \& Supomo. (2002). Metodologi Penelitian Bisnis untuk Akuntansi dan Manajemen. Yogyakarta: BPFEYogyakarta.

International Financial Services Board Report (IFSB) (2017), "Islamic financial services board", Available at: https://doi.org/10.1109/IHMSC.2011.82

lqbal Z, Mirakhor A (2007). An Introduction to Islamic Finance: Theory and Practice. John Wiley \& Sons (Asia), Singapore. Prospectus
Janwari, Y. (2015). Lembaga Keuangan Syariah. Bandung: Remaja Rosdakarya Offset.

Karim, A. (2010). Analisis Fiqih dan Keuangan Bank Islam. Jakarta: PT Raja Grafindo Persada

Kuncoro, M. (2012). Manajemen Perbankan: Teori dan Aplikasi. Yogyakarta: BPFE.

Linda, S. (2019). Analysis of The Effect of ThirdParty Fund, Murabahah Non-Performing Finance, And Inflation on Murabahah Financing in Sharia Commercial Banks in Indonesia. Jurnal Manajemen Perbankan Syariah.

Mardani. (2011). Ayat-Ayat dan Hadis Ekonomi Syariah. Jakarta: Rajawali Pers.

Muhammad. (2002). Manajemen Bank Syariah. Yogyakarta: UPP STIM YKPN.

Otoritas Jasa Keuangan. (2018). Indonesia Sharia Banking Statistics. Jakarta.

Prabowo, B. A. (2012). Aspek Hukum Pembiayaan Murabahah pada Perbankan Syariah. Yogyakarta: UII Press.

Rahmawati, F. A. \& Rokhman W. (2015). Analisis Faktor yang Mempengaruhi Penetapan Margin pada Pembiayaan Murabahah di BMT Se-Kabupaten Jepara. Equilibrium, 3, 238-253.

Republik Indonesia. (2008). Undang-Undang No. 21 Tahun 2008 tentang Perbankan Syariah. Jakarta: Sekretariat Negara.

Riyadi, Slamet, (2006). Banking Assets And Liability Management. Jakarta: Lembaga Penerbit Fakultas Ekonomi Universitas Indonesia,.

Saeed, A. (1998). Idealism and pragmatism in Islamic Banking: The application of shari'ah principles and adjustments. Journal of Arabic Islamic and Middle Eastern Studies, 4, 89-111.

Sri, (2018). Analysis of Factors that Influence Murabahah Financing in Islamic Banking, Jurnal Fakultas Ekonomi Universitas Pandanaran Semarang, 2-14.

Sulhan, M. dan Ely Siswanto. (2008). Manajemen Bank : Konvensional dan Syariah. Malang : UIN-Malang Press.

Usmani, M.T. 2003. Murabaha an online Publication by Accounting.com 